\title{
Esophageal Well Differentiated Squamous Cell Carcinoma
}

National Cancer Institute

\section{Source}

National Cancer Institute. Esophageal Well Differentiated Squamous Cell Carcinoma. NCI

Thesaurus. Code C95610.

An esophageal squamous cell carcinoma characterized by the presence of prominent keratinization and low mitotic activity. 